\title{
Can Activity Projects Improve Children's Wellbeing during the Transition to Secondary Education?
}

\author{
Jane Akister ${ }^{1}$, Hannah Guest ${ }^{1} \&$ Sarah Burch $^{1}$ \\ ${ }^{1}$ Faculty of Health, Social Care and Education, Anglia Ruskin University, Cambridge, UK \\ Correspondence: Jane Akister, Faculty of Health, Social Care and Education, Anglia Ruskin University, Young \\ Street Site, East Road, Cambridge CB1 1PT, UK. E-mail: jane.akister@anglia.ac.uk
}

Received: April 29, 2016

Accepted: June 1, 2016 Online Published: November 24, 2016

doi:10.5539/ies.v9n12p1

URL: http://dx.doi.org/10.5539/ies.v9n12p1

\begin{abstract}
Promoting child mental wellbeing is an important part of UK early intervention policy. Children with poor physical or mental health have significantly lower educational attainment and lower social status as adults. 'Activity' projects are one form of early intervention used to try and help vulnerable children. Evidence relating to the effectiveness of activity programmes is limited and there is little to say which children benefit most.

This paper reports on a summer activity project for children identified as vulnerable in the transition from primary to secondary school and is a repeat measures, longitudinal design. Reasons that children were referred to the transition project included concerns about their behaviour, school attendance, self-confidence and self-esteem. Pre-project Strengths and Difficulties Questionnaires show that most of these children have borderline or high Overall Stress scores, suggesting teachers are right to be concerned about them. The most significant improvement following the project was for children with high scores for emotional distress. There were no improvements for children referred for behavioural concerns.
\end{abstract}

Keywords: activity projects, transition, secondary education, wellbeing, mental health

\section{Introduction}

Promotion of child mental wellbeing is an important part of UK early intervention policy (DH, 2015). There is a specific concern about children who are 'at risk' or disadvantaged. The 1958 birth cohort studies find that health is a 'potential mechanism through which intergenerational transmission of economic status takes place'. Children who had poorer health had significantly lower educational attainment and lower social status as adults. When controlling for other factors health still predicted these risks, with mental health even more strongly linked to poor outcomes than physical health (Richards \& Abbott, 2009). Early intervention, in terms of the mental health of children, is needed, as we begin to fully understand the impact that poor mental health as a child has on achievement as an adolescent and also as an adult (Case, Fertig, \& Paxson, 2005).

However, Merry and Spence (2007), in reviewing the literature of programmes aimed to help children with depressive symptoms, show ambiguous and conflicting findings with no conclusive evidence that programmes can reduce depressive symptoms in adolescents. There is also a suggestion that attendance for targeted interventions was a widespread problem-young people who are at most risk may be least likely to attend. If early intervention is indicated then this may need to occur before adolescence.

\subsection{Poor Educational Achievement}

It is hard to separate out the contribution of mental wellbeing to educational outcomes as the two are closely intertwined. Poor educational achievement is highlighted in the literature as a risk factor for becoming NEET (Not in Education, Employment or Training). An analysis of the U.K. 1970 birth cohort found that young people with no qualifications were six times more likely to become NEET than those with qualifications (Bynner \& Parsons, 2002). Factors which can be linked to poor educational attainment have been explored and include negative school experiences, lack of self-confidence and self-esteem, and persistent truancy (Furlong, 2006; Sachdev, Harries, \& Roberts, 2006). The location of the study reported in this paper has high levels of NEET (Sadler, Akister, \& Burch, 2014) and this is why the participating schools have proposed this research which explores the impact of summer activity projects, designed to promote an effective transition between primary and secondary school. The underpinning assumption of such projects is that a smooth transition will lead to 
greater pupil wellbeing, hence offering the potential for improved educational achievement. Summer activity projects can be considered as one form of early intervention.

\subsection{Early Intervention Models}

Early intervention models identify the person or group of people who are at risk due to certain characteristics or behaviour. The need to change is less prominent in early intervention; instead there is a need to learn skills and tools that can act as a protective factor against projected risks later in life. Early interventions thus can be used to try to help vulnerable children. However, the evidence as to whether they are effective or benefit all children equally is mixed. Looking first at evaluations of early intervention programmes, timing seems quite critical. Reports on interventions with young primary age children, aged 3-7 years, suggest they have success in helping with conduct problems (Broadhead, Hockaday, Zahra, Francis, \& Crichton, 2009). For older children, aged 9-10 years interventions designed to develop coping mechanisms to manage anxiety are reported as effective (Collins, Woolfson, \& Durkin, 2013). A study aimed at improving depressive symptoms in children aged age 10-11, using cognitive and problem solving skills found a decrease in depressive symptoms and improved explanatory style on follow-up (Gillham, Reivich, Jaycox, \& Seligman, 1995) whereas a similar study with 12 year old children who had already moved to secondary school found little sustained benefit (Roberts, Kano, Thompson, \& Bishop, 2003). (See Appendix for studies which assess outcomes from early intervention).

It must be acknowledged that it is very hard to show that any type of early intervention reliably improves outcomes for young people. Part of the problem lies in the fact that any attempts at early intervention will include children who already in need of more help than has been realised and so they may appear worse following an intervention, simply because the work has uncovered a greater level of need than was apparent. Conversely, those children who would improve without intervention would be included in the programme. Statham \& Smith (2010) review the literature on identifying and supporting children with additional needs and find that while there is a lot of evidence suggesting some benefits for early intervention, the findings can be contradictory, are not readily generalizable and that targeting interventions is politically unpopular.

\subsection{Activity Projects}

Together with the variable findings supporting early intervention approaches, it is very difficult to evidence effectiveness for activity programmes in general on the emotional and social wellbeing of 'at risk' youth (Lubans, Plotnikoff, \& Lubans, 2012; see Appendix). After reviewing 15 physical activity programmes, Lubans et al. (2012) find that the standard of evidence collected is not always high, that 4 programmes showed no effect and that the interventions need to be more specifically tailored to the needs of the young people. They speculate that what leads to improvement is largely the new environment offered by the programmes.

Where do summer activity projects aimed at the transition from primary to secondary education fit in? There are a range of practices which individual schools may adopt in order to help prepare children for joining secondary education, including visits, talks and information-sharing (Evangelou et al., 2008). In 2011, the UK government announced that $£ 50$ million would be available in order to support disadvantaged pupils through a summer schools programme, and schools were invited to apply for funding (Day et al., 2013). A large survey of the impact of summer programmes in the UK suggests that these projects are popular with the children, who report feeling less anxious about attending their new secondary school. However, it was not evident that there was any beneficial impact when they transited to secondary school and there is no indication of how specifically to engage those children who may be disadvantaged (Sharp \& Mehta, 2013; see appendix). Siddiqui, Gorard, and Huat (2014) report on a universal summer project with educational components where again there are no clear results from the programme. A small targeted project aimed at children at risk of disengaging from education again finds children feeling more confident in the transition but there is little evidence of sustained improvement on follow-up (Carmen, Woycott, \& Smith, 2011; see Appendix).

Activity projects seem to have potential to improve children's sense of wellbeing, but the questions of when they might be most effective and how they should be targeted remain challenging. The interplay between teachers' concerns, children's additional needs and the impact of early intervention strategies is complex.

The research reported on here uses the SDQ (Strength and Difficulties Questionnaires; Goodman \& Goodman, 2009) to track children over a two year period. The children were identified by their teachers who were concerned about how they would manage in the transition to secondary school. Before starting secondary school these children were offered a summer activity programmes, to try and improve their chances of engaging successfully in secondary education. The literature on early intervention and activity projects yields mixed findings and relies heavily on self-report and qualitative methods. The study reported on in this paper used a standardised quantitative measure (SDQ) to try to address some of these criticisms. 


\section{Method}

The local Children's Trust was concerned about children disengaging with education on the transition to secondary school. This project was developed in collaboration between the Children's Trust, Head teachers and Anglia Ruskin University. The project proposed to look at the mental wellbeing of children age 10-11 years, prior to their transition to secondary school and follow them up a year later. The children (aged 10-11 years) were identified, by their teachers, as vulnerable in the transition from primary to secondary school. Ten primary schools were involved in the study, feeding into 2 comprehensive secondary schools. The schools were located in an isolated rural area in the East of England.

Teachers identified children that they were concerned about and then, with parental consent, completed a standardised measure of wellbeing (The Strengths and Difficulties Questionnaire (SDQ)) and a reason for concern form before referring them to the summer activity project. The $\boldsymbol{S D Q}$ is a widely used measure of child mental health (A. Goodman \& R. Goodman, 2009). Children with higher total difficulty scores have been found to have greater psychopathology as judged by the prevalence of clinical disorder. The SDQ gives an overall stress rating and has 5 sub-scales: Emotional Distress; Hyperactivity; Difficulties getting along with other Young People; Behavioural Difficulties; Kind and Helpful Behaviour. The resulting score can be reliably categorised as normal, borderline or high indicating psychological, social, emotional and behavioural disorders (A. Goodman \& R. Goodman, 2009). A Reason for Concern form was also completed by teachers, together with the SDQ. The options listed on the form were: Learning Needs; Behaviour; Attendance; Anxiety; Self-esteem; Other.

These children were offered a summer holiday transition programme and were followed up a year later, at the end of their first year at secondary school when repeat SDQs were completed by the children's tutors. The transition programme consisted principally of a series of after-school activities in July followed by summer school activity days. These days consisted of activities such as a treasure hunt to promote orientation, a trip out, art and craft and sports. Children were supported throughout by peer mentors, and there were follow-up events in the autumn.

Ethical approval was given by the Anglia Ruskin Faculty Research Ethics Panel, and consent was sought from all parents whose children were identified as in need of additional support in the transition to secondary school, to allow their children's teachers to complete the SDQ and reason for concern form. SDQ questionnaires were returned for 48 children at the end of year 6 and 39 children at the end of year 7. Ideally it would have been helpful to have a control group, but the ethics of identifying children as vulnerable and not intervening meant that this was not considered an appropriate option. An alternate approach for future research might be to screen a whole class. This is discussed later in the paper.

\section{Results}

\subsection{SDQ Scores at Primary School (Year 6) and On Follow-Up at the End of Year 7}

The SDQ and reasons for concern form were completed by school staff at the end of Year 6 and then again at the end of year 7, after the transitional summer activity project and when the children had completed a year in secondary school. At the outset, in year $6,65 \%$ of the children about whom the teachers had concerns scored high or borderline on the SDQ Overall Stress scale, with 35\% scoring in the normal range. By the end of year 7 only $31 \%$ score as high or borderline on the SDQ Overall Stress scale, with $69 \%$ scoring in the normal range (see Table 1). This suggests that the teachers are accurate in identifying children of concern and that there is capacity for improved mental wellbeing at this transitional point. The subscale where there is most change in the high category is Emotional Distress which falls from $40 \%$ at the end of year 6 to $15 \%$ at the end of year 7 . There is no significant difference here between boys and girls. In the high category, other subscales remain relatively stable between years 6 and 7 (see Table 1). 
Table 1. SDQ scores for whole cohort at Years 6 and 7

\begin{tabular}{|c|c|c|c|c|c|c|}
\hline \multirow[t]{4}{*}{ SDQ Scales } & \multicolumn{6}{|c|}{ SDQ Score (Teacher) } \\
\hline & \multicolumn{2}{|c|}{ Normal } & \multicolumn{2}{|c|}{ Borderline } & \multicolumn{2}{|c|}{ High } \\
\hline & Year 6 & Year 7 & Year 6 & Year 7 & Year 6 & Year 7 \\
\hline & $\mathrm{n}=48$ & $\mathrm{n}=39$ & $\mathrm{n}=48$ & $\mathrm{n}=39$ & $\mathrm{n}=48$ & $\mathrm{n}=39$ \\
\hline Overall Stress & $\begin{array}{c}17 \\
(35 \%)\end{array}$ & $\begin{array}{c}27 \\
(69 \%)\end{array}$ & $8(17 \%)$ & $7(18 \%)$ & $23(48 \%)$ & $5(13 \%)$ \\
\hline Emotional Distress & $25(52 \%)$ & $31(79 \%)$ & $4(8 \%)$ & $2(5 \%)$ & $19(40 \%)$ & $6(15 \%)$ \\
\hline Hyper-activity & $18(38 \%)$ & $17(44 \%)$ & $10(21 \%)$ & $6(15 \%)$ & $20(42 \%)$ & $16(41 \%)$ \\
\hline Difficulties getting along with other Young People & $31(65 \%)$ & $23(59 \%)$ & $5(10 \%)$ & $7(17 \%)$ & $12(25 \%)$ & $9(23 \%)$ \\
\hline Behavioural Difficulties & $34(71 \%)$ & $26(67 \%)$ & $3(6 \%)$ & $6(15 \%)$ & $11(23 \%)$ & $7(18 \%)$ \\
\hline Kind and Helpful Behaviour & $27(56 \%)$ & $22(56 \%)$ & $15(31 \%)$ & $8(17 \%)$ & $6(12 \%)$ & $9(23 \%)$ \\
\hline
\end{tabular}

\subsection{Reasons for Concern and SDQ Scores}

Teachers were able to select one or more reasons for concern. So, for example, there were 19 children with high SDQ scores for emotional distress at the end of year 6 and the teachers were also concerned about the self-esteem of 15 of them and about the attendance of 7 of them (see Table 2). By the end of year 7, for those 6 children with high SDQ scores for emotional distress, the teachers are concerned about the self-esteem of all six of those children scoring with emotional distress and about the attendance of 2 of them (see Table 2).

Table 2. Teacher reason for concern and high SDQ scores by category

\begin{tabular}{|c|c|c|c|c|c|c|c|}
\hline & & \multicolumn{6}{|c|}{ SDQ Category } \\
\hline & & $\begin{array}{l}\text { Overall } \\
\text { Stress }\end{array}$ & $\begin{array}{c}\text { Emotional } \\
\text { Distress }\end{array}$ & Hyper activity & $\begin{array}{c}\text { Difficulty } \\
\text { Getting Along } \\
\text { with other } \\
\text { Young People }\end{array}$ & $\begin{array}{l}\text { Behaviour } \\
\text { Difficulty }\end{array}$ & $\begin{array}{c}\text { Kind and } \\
\text { Helpful } \\
\text { Behaviour }\end{array}$ \\
\hline Yr6/Yr7 & $n=48 / n=30$ & $\mathrm{n}=23 / \mathrm{n}=5$ & $n=19 / n=6$ & $n=20 / n=6$ & $\mathrm{n}=12 / \mathrm{n}=9$ & $\mathrm{n}=11 / \mathrm{n}=7$ & $\mathrm{n}=6 / \mathrm{n}=9$ \\
\hline \multirow{5}{*}{$\begin{array}{l}\text { Reason for } \\
\text { Concern }\end{array}$} & 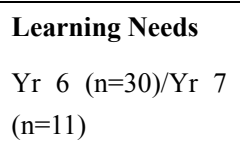 & $14 / 8$ & $11 / 1$ & $12 / 8$ & $7 / 7^{*}$ & $6 / 4 *$ & $3 / 4$ \\
\hline & $\begin{array}{l}\text { Behaviour } \\
\mathrm{Yr} \quad 6 \quad(\mathrm{n}=15) / \mathrm{Yr} 7 \\
(\mathrm{n}=13)\end{array}$ & $11 * / 9$ & $4 * / 1$ & $12 * / 7$ & $3 / 2$ & $10^{* * / 4}$ & $4 * / 5 *$ \\
\hline & $\begin{array}{l}\text { Attendance } \\
\text { Yr6 } \quad(n=7) / Y r 7 \\
(n=3)\end{array}$ & $7 * / 3$ & $7 * / 2$ & $1 / 1$ & $4 / 1$ & $0 / 0$ & $0 / 0$ \\
\hline & $\begin{array}{l}\text { Anxiety } \\
\operatorname{Yr} \quad 6 \quad(n=18) / Y r 7 \\
(n=3)\end{array}$ & $14 * / 3$ & $15 * * / 1 *$ & $9 / 0$ & $9 * / 2$ & $5 / 0$ & $3 / 0$ \\
\hline & $\begin{array}{l}\text { Self-esteem } \\
\text { Yr6 } \quad(n=30) / Y r 7 \\
(n=11)\end{array}$ & $18 / 8$ & $15 / 6^{*}$ & $17 * / 4$ & $9 * / 2$ & $6 / 0$ & $4 / 2$ \\
\hline
\end{tabular}

Fishers Exact test, ${ }^{*} \mathrm{p}<0.05 ;{ }^{* *} \mathrm{p}<0.001$.

Looking at teachers' reasons for concern and where these relate to subscales of the SDQ, we find fewer 
statistically significant relationships at the end of year 7 (see Table 2). Taking each area of concern from teachers:

\subsubsection{Learning Needs}

The number of children where teachers are concerned about learning needs falls from 30 at the end of year 6 to 11 at the end of year 7. But for these 11 there are statistically significant relationships between teacher concern about learning needs and SDQ scores for behaviour difficulties and getting along with other young people (see Table 2). Those children where there are still concerns about learning needs seem to have developed other areas of difficulty in terms of their mental wellbeing as measured by the SDQ, and this is reflected in the school setting. Perhaps those children where teacher concern about learning needs persist, struggle more in the secondary environment where they need to relate to a wider range of teachers and follow written instructions.

\subsubsection{Behaviour}

The number of children with teacher concerns about behaviour falls from 15 to 13 but there are no statistically significant relationships with the SDQ reported apart from with kind and helpful behaviour. This is interesting as the activity programme appears to have had no effect on behaviour and while it is a problem in terms of using the learning environment and social adjustment, it impacts less on mental wellbeing. Alternatively, the externalizing nature of the behaviour masks problems in mental wellbeing such as anxiety (Mrug, 2012).

\subsubsection{Attendance}

The number of children with teacher concern about attendance decrease from 7 to 3 and there are no statistically significant relationships with the SDQ scores at the end of year 7. At the year 6 stage there were statistically significant relationships between attendance and overall stress and emotional distress (see Table 2). This suggests that where there have been improvements in emotional distress these children have engaged with the secondary school and are now attending.

\subsubsection{Anxiety}

The number of children with teacher concern about anxiety have fallen from 18 to 3 at the end of year 7 . There is still a statistically significant relationship with SDQ score for emotional distress at the end of year 7 . The summer activity project had most impact on this area of teacher concern. The content of activity programmes focus on self-efficacy and self-confidence suggesting that they are effective in the areas that relate most closely to their objectives. This supports the need to target programmes and not deliver them universally, as if they can meet all needs.

\subsubsection{Self-Esteem}

Again the number of children where there is teacher concern at the end of year 7 is much lower. There is a statistically significant relationship between teacher concern about anxiety and SDQ scores for emotional distress (see Table 2).

\subsection{Children Who Are No Longer of Concern at the End of Year 7}

When the children were referred to the project at the end of year 6,48\% scored in the high category for Overall Stress; by the end of year 7 only $13 \%$ score in the high category for Overall Stress (see Table 1).

Exploring this in more detail, on follow up there were 7 children about whom the teachers had no concerns. These children, about whom there is no longer any concern, come from all three categories of overall stress in year 6-normal, borderline and high. The original reasons for concern about these children are presented in Table 3.

Table 3. The 7 children who are no longer of concern at the end of Year 7

\begin{tabular}{cccccc}
\hline & \multicolumn{5}{c}{ Reason for Concern in Year 6 } \\
\cline { 2 - 6 } & Learning Needs & Behaviour & Attendance & Anxiety & Self-Esteem \\
\hline Child 1 & x & $\checkmark$ & x & x & x \\
Child 2 & $\checkmark$ & x & x & x & $\checkmark$ \\
Child 3 & x & x & x & x & $\checkmark$ \\
Child 4 & $\checkmark$ & x & $\checkmark$ & $\checkmark$ & $\checkmark$ \\
\hline
\end{tabular}




\begin{tabular}{llllll}
\hline Child 5 & $\checkmark$ & $\mathrm{x}$ & $\mathrm{x}$ & $\mathrm{x}$ & $\checkmark$ \\
Child 6 & $\checkmark$ & $\mathrm{x}$ & $\mathrm{x}$ & $\mathrm{x}$ & $\checkmark$ \\
Child 7 & $\mathrm{x}$ & $\checkmark$ & $\mathrm{x}$ & $\checkmark$ & $\checkmark$ \\
\hline
\end{tabular}

In 6 of these cases, teachers were concerned in year 6 about the children's self-esteem; they were also concerned about learning needs in 4 of these cases. Something has occurred between the end of primary school and the end of the first year of secondary school to improve both these factors for these children. Potentially, improved confidence following the transitions programme has enabled them to make better use of the learning environment in secondary school.

\subsection{Summary of Results}

Reasons that children were referred to the summer transition project include concerns about their behaviour, attendance, self-confidence and self-esteem. Pre-project SDQs $(n=48)$ show that most of these children have borderline or high Overall Stress scores (65\%; see Table 1). Following the summer activity project and support during the transition, borderline or high Overall Stress scores at the end of year 7 fell to $31 \%$. The most significant change was for children with high SDQ scores for emotional distress with a decrease of borderline and high scores from $48 \%$ to $20 \%$ (see Table 1). The summer transition project aims to familiarise children with their new setting and to enable them to meet new peers. The focus is on confidence building. The decrease in SDQ scores in the high category for overall stress, with improved subscales in self-esteem and anxiety, suggests success in the activity based intervention (see Table 2). For children referred for concerns about behaviour there was no improvement in their Overall Stress scores.

These results were shared with the project leaders who found no obvious reason for the lack of impact of their transitions programme on behaviour. Most transitional programmes are designed to familiarise the children with new environments, offer opportunities to meet new peers and are generally designed to promote socialisation and grow confidence. Children with behaviour issues are often quite confident and social and this may be why this programme did not have any positive impact on behaviour. Targeting programmes to maximise their effect is critical to any positive outcomes.

\section{Discussion}

As stated in the introduction it is very difficult to evidence effectiveness for activity programmes on the emotional and social wellbeing of 'at risk' youth (Lubans et al., 2012). It is also very hard to show that early intervention of any sort improves outcomes for children and young people. Additionally, Sellers, Maughan, Pickles, Thapar, and Collinshaw (2015) report that while there is a marked increase in Western countries in diagnosis and treatment of child psychiatric disorders, there is a decline in parent and teacher rated perceived levels of emotional and behavioural problems in pre-pubertal children (using SDQ scores). They report a novel finding that, "while overall problem levels reduced, the perceived impact of emotional and behavioural problems increased. In particular, where children were rated as having difficulties, parents and teachers reported greater impairment...' (Sellers et al., 2015). Combined with the increase in referral to child psychiatric services this suggests a change in thresholds for identifying mental disorder.

Akister (2013) reports mixed results for a small activity intervention (ROAR project; $n=11$ ) run over 12 weeks in the final term of Year 6 with improvement in emotional symptoms for some children and no improvements for those children where the concerns were behaviour difficulties or hyperactive behaviour. These findings articulate with the findings in this research; although the content of the activity projects was quite different, both had similar aims to engage the pupils in the school setting and improve confidence. Gillham et al. (1995) also suggest that age 10/11 years is a good time to intervene. Their study taught cognitive and problem-solving skills to children with high scores on the Child Depression Inventory (CDI). Overall in our research, the subscale of the SDQ with greatest improvement was emotional distress (see Table 1). There was no change in the percentage of children with hyperactive behaviour or behavioural difficulties.

Engagement in education is critical to future life chances. Poor educational achievement is highlighted in the literature as a risk factor for becoming NEET (Bynner \& Parsons, 2002; Furlong, 2006). Factors which can be linked to poor educational attainment include negative school experiences, lack of self-confidence and self-esteem, and persistent truancy. The Summer Transitions project in our research seems to have had greatest impact in the area of self-esteem and anxiety, which if maintained would suggest that these children will be able to make better use of the educational opportunities they receive and achieve improved outcomes. 
This is a small-scale study, with a non-randomised sample, therefore any conclusions drawn must be tentative. However, the SDQ (Strengths and Difficulties Questionnaire) scores for Overall Stress suggest an improvement in wellbeing for many of the children in the study (see Table 1). Since all children in the study were identified as 'vulnerable' in the transition to secondary school this represents a good achievement for the summer transition project with good correlation between teachers concerns about self-esteem and anxiety with SDQ scores for emotional distress. The Summer Transitions Project had a positive impact on student's emotional distress and self-confidence. A limitation of the study is the lack of a control group. While it was not considered ethical to collect a control group without intervention, it would be interesting to compare the mental wellbeing of those children identified by teachers as vulnerable in the transition to secondary school, with the rest of the peers in their class. We plan to take this idea forward to explore further the findings that suggest targeted interventions are to be preferred to universal interventions to promote the wellbeing of young people.

\section{Conclusions}

The subscale of the SDQ where there is most improvement in the high category is Emotional Distress. There is good correlation between teachers' concerns about self-esteem and anxiety with SDQ scores for emotional distress at the end of year 6 . At the end of year 7 children who are still identified with learning needs experience difficulties getting along with their peers and are likely to have behavioural difficulties too. Where children raise concern because of their behaviour, the transitional activity project has little impact.

The findings from the Fenland Area Project propose that transitional activity projects affect the emotional wellbeing of pupils, with limited impact on externalising behaviour. This would suggest that by targeting the projects on pupils with emotional symptoms, identified through teachers concerns about self-esteem and anxiety, the projects can have a positive impact on the wellbeing of the young people. In turn, improved self confidence and self-esteem could be expected to lead to improved educational attainment and to improved adult wellbeing for the young people.

It is common to offer early interventions as universal programme to all children who are of concern, and there is a reluctance to target programmes. Our findings suggest that referrals need to be refined to target those children who may benefit from such programmes. If children with behaviour issues do not benefit from these programmes they need a different approach focussed on behaviour. This may be quite an important finding because attending a programme that does not improve behaviour may well be counterproductive and also means no other programme will be offered. Since early intervention appears to be most effective before secondary education the nature and timing of intervention is critical.

It is important to recognise that these projects will not be successful for all children and do not appear to improve outcomes for children about whom the concerns are about behaviour. As a consequence it is important to match the aims of any early intervention programme with the target group of children. Key to successful outcomes is placing children in programmes specifically designed to meet their needs.

\section{Acknowledgements}

This project was funded by Cambridgeshire Children's Trust and Anglia Ruskin University. We are very grateful to the schools and families who participated in the project and to Lorraine Lofting, Anna Wahlandt and Jill Buckingham who facilitated the work with the schools.

\section{References}

Akister, J. (2013). SDQ Analysis for Roar Project. Report for Sawston Locality Team.

Broadhead, M. A., Hockaday, A., Zahra, M., Francis, P. J., \& Crichton, C. (2009). Scallywags-An evaluation of a service targeting conduct disorders at school and at home. Educational Psychology in Practice, 25(2), 167-179. http://dx.doi.org/10.1080/02667360902905270

Bynner, J., \& Prsons, S. (2002). Social exclusion and the transition from school to work: The case of young people not in education, employment, or training (NEET). Journal of Vocational Behavior, 60(2), 289-309. http://dx.doi.org/10.1006/jvbe.2001.1868

Carmen, B., Waycott, L., \& Smith, K. (2011). Rock up: An initiative supporting students' wellbeing in their transition to secondary school. Children and Youth Services Review, 33(1), 167-172. http://dx.doi.org/10.1016/j.childyouth.2010.08.030

Case, A., Fertig, A., \& Paxson, C. (2005). The lasting impact of childhood health and circumstance. Journal of Health Economics, 24(2), 365-389. http://dx.doi.org/10.1016/j.jhealeco.2004.09.008

Collins, S., Woolfson, L. M., \& Durkin, K. (2013). Effects on coping skills and anxiety of a universal school-based 
mental health intervention delivered in Scottish primary schools. School Psychology International. http://dx.doi.org/0143034312469157.

Day, L., Martin, K., Sharp, C., Gardner, R., \& Barham, J. (2013). Summer school programme for disadvantaged pupils. London: Department for Education. Retrieved from https://www.gov.uk/government/uploads/system/ uploads/attachment_data/file/197198/DFE-RR271B.pdf

Department of Health. (2015). Promoting emotional wellbeing and positive mental health of children and young people. Retrieved from https://www.gov.uk/government/uploads/system/uploads/attachment_data/file/ 299268/Emotional_Health_and_Wellbeing_pathway_Interactive_FINAL.pdf Accessed 3.3.2015.

Evangelou, M., Taggart, B., Sylva, K., Melhuish, E., Smmons, P., \& Siraj-Blatchford, I. (2008). What makes a successful transition from primary to secondary school? Research report no: DCSF-RR019. London: Department for Children, Schools and Families, Retrieved from http://webarchive.nationalarchives.gov.uk/ 20130401151715/http://www.education.gov.uk/publications/eOrderingDownload/DCSF-RR019.pdf

Furlong, A. (2006). Not a very NEET solution. Work, Employment \& Society, 20(3), 553. http://dx.doi.org/10.1177/0950017006067001

Gillham, J. E., Reivich, K. J., Jaycox, L. H., \& Seligman, M. E. (1995). Prevention of depressive symptoms in schoolchildren: two-year follow-up. Psychological Science, 343-351.

Goodman, A., \& Goodman, R. (2009). Strengths and difficulties questionnaire as a dimensional measure of child mental health. Journal of the American Academy of Child and Adolescent Psychiatry, 48, 400-403. http://dx.doi.org/10.1097/CHI.0b013e3181985068

Goodman, R. (1997). The strengths and difficulties questionnaire: A research note. Journal of Child Psychology and Psychiatry, 38(5), 581-586. http://dx.doi.org/10.1111/j.1469-7610.1997.tb01545.x

Goodman, R., Ford, T., Simmons, H., Gatward, R., \& Meltzer, H. (2000). Using the strengths and difficulties questionnaire (SDQ) to screen for child psychiatric disorders in a community sample. British Journal of Psychiatry, 177, 534-539. http://dx.doi.org/10.1192/bjp.177.6.534

Lubans, D. R., Plotnikoff, R. C., \& Lubans, N. J. (2012). Review: A systematic review of the impact of physical activity programmes on social and emotional wellbeing in at-risk youth. Child and Adolescent Mental Health, 17, 2-13. http://dx.doi.org/10.1111/j.1475-3588.2011.00623.x

Martin, K., Sharp, C., \& Mehta, P. (2013). The impact of the summer schools programme on pupils. Report to National Foundation for Educational Research.

Merry, S. N., \& Spence, S. H. (2007). Attempting to prevent depression in youth: A systematic review of the evidence. Early Intervention in Psychiatry, 1, 128-137. http://dx.doi.org/10.1111/j.1751-7893.2007.00030.x

Mrug, S., Molina, B. S., Hoza, B., Gerdes, A. C., Hinshaw, S. P., Hechtman, L., \& Arnold, L. E. (2012). Peer rejection and friendships in children with attention-deficit/hyperactivity disorder: Contributions to long-term outcomes. Journal of abnormal child psychology, 40(6), 1013-1026. http://dx.doi.org/10.1007/s10802-012-9610-2

Richards, M., \& Abbott, R. (2009). Childhood mental health and life chances in post-war Britain. Sainsbury's Centre for Mental Health.

Roberts, C., Kane, R., Thomson, H., Bishop, B., \& Hart, B. (2003). The prevention of depressive symptoms in rural school children: A randomized controlled trial. Journal of consulting and clinical psychology, 71(3), 622. http://dx.doi.org/10.1037/0022-006X.71.3.622

Sachdev, D., Harries, B., \& Roberts, T. (2006). Regional and sub-regional variation in NEETs-reasons, remedies and impact. Learning and Skills Development Agency.

Sadler, K., Akister, J., \& Burch, S. (2014). Who are the young people who are not in education, employment or training? An application of the risk factors to a rural area in the UK. International Social Work, 58(4), 508-520. http://dx.doi.org/0020872813515010.

Sellers, R., Maughan, B., Pickles, A., Thapar, A., \& Collinshaw, S. (2015). Trends in parent- and teacher-rated emotional, conduct and ADHD problems and their impact in pre-pubertal children in Great Britain 1999-2008. Journal of Child Psychology and Psychiatry, 56(1), 49-57. http://dx.doi.org/10.1111/jcpp.12273

Siddiqui, N., Gorard, S., \& See, B. H. (2014). Is a summer school programme a promising intervention in preparation for transition from primary to secondary school? International Education Studies, 7(7), 125-135. 
http://dx.doi.org/10.5539/ies.v7n7p125

Statham, J., \& Smith, M. (2010). Issues in Earlier Intervention: Identifying and supporting children with additional needs. Institute of Education, University of London: Thomas Coram Research Unit.

\section{Appendix}

\section{Outcomes from Early Intervention Programmes}

\begin{tabular}{|c|c|c|c|c|}
\hline Author(s)/Title & Country/Date & Sample & Type of Intervention & Results/Comments: \\
\hline $\begin{array}{l}\text { Broadhead, M. } \\
\text { Hockaday, A. Zahra, } \\
\text { M. Francis, P. Crichton, } \\
\text { C. } \\
\text { Scallywags - An } \\
\text { evaluation of a service } \\
\text { targeting conduct } \\
\text { disorders at school and } \\
\text { at home. }\end{array}$ & 2009 & $\begin{array}{l}411 \text { children aged between } 3 \\
\text { and } 7 . \\
\text { Semi-rural Cornwall. } \\
\text { Conduct problems identified } \\
\text { by care giver and professional } \\
\text { referral. } \\
\text { Pre and post measurements } \\
\text { from parents and teachers: } \\
\text { 1. Eyberg Child Behavior } \\
\text { Inventory; } \\
2 . \quad \text { Sutter-Eyberg Student } \\
\text { Behavior Inventory- Revised. }\end{array}$ & $\begin{array}{l}6 \text { months: } \\
\text { Family Support } \\
\text { Worker - } 3 \text { hours at } \\
\text { home and } 5 \text { hours } \\
\text { per week with the } \\
\text { child. } \\
\& \\
\text { Parents group for } 10 \\
\text { weeks where parents } \\
\text { learn and discuss } \\
\text { effective ways to } \\
\text { parent their children. }\end{array}$ & $\begin{array}{l}\text { Less conduct problems reported by } \\
\text { parents and teachers. } \\
\text { For children in the clinical range of } \\
\text { conduct disorder symptoms } 60 \% \text { had } \\
\text { scores below clinical range after } \\
\text { intervention and at follow up. } \\
\text { High levels of intervention and } \\
\text { contact with sustained benefits } \\
\text { reported but the longest follow up is } 6 \\
\text { months. } \\
\text { Parents and teachers weren't blind to } \\
\text { intervention, potential for high levels } \\
\text { of bias in post-intervention scores. } \\
\text { Report relies on qualitative data to } \\
\text { show the change in the children. }\end{array}$ \\
\hline $\begin{array}{l}\text { Carmen, B. Waycott, L. } \\
\text { Smith, K. } \\
\text { Rock up: an initiative } \\
\text { supporting students } \\
\text { wellbeing in their } \\
\text { transition to secondary } \\
\text { school. }\end{array}$ & $\begin{array}{l}\text { Australia } \\
2011\end{array}$ & $\begin{array}{l}\text { Years 5,6 and } 7 \text { (ages 9-11). } \\
13 \text { children. } \\
\text { Referred by teacher and parent } \\
\text { due to being at risk of } \\
\text { disengaging from education. }\end{array}$ & $\begin{array}{l}\text { Aimed to facilitate } \\
\text { transition and to } \\
\text { promote the } \\
\text { wellbeing of the } \\
\text { children. } \\
\text { Weekly sessions, } \\
\text { following themes } \\
\text { each week either: } \\
\text { 1. Individual - } 1 \\
\text { hour; } \\
\text { 2. Group - } 2 \text { hours; } \\
\text { 3. Combined - } 4 \\
\text { were given } \\
\text { individual help } \\
\text { following group. }\end{array}$ & $\begin{array}{l}\text { Students reported they were more } \\
\text { confident, more resilient and no } \\
\text { longer scared about entering year } 7 \text {. } \\
\text { Parents agreed. They largely liked the } \\
\text { program. } \\
\text { Small sample for } 3 \text { interventions. } \\
\text { Report relies on qualitative feedback. } \\
\text { Very little sustained improvements } \\
\text { from pre to follow up data. Hard to } \\
\text { argue benefits from the programme } \\
\text { would be sustained. }\end{array}$ \\
\hline $\begin{array}{l}\text { Effects on coping skills } \\
\text { and anxiety of a } \\
\text { universal school-based } \\
\text { mental health } \\
\text { intervention delivered } \\
\text { in Scottish primary } \\
\text { schools. }\end{array}$ & $\begin{array}{l}\text { Scotland } \\
2013\end{array}$ & $\begin{array}{l}307 \text { pupils, randomly allocated } \\
\text { to control or intervention. } \\
\text { Schools were matched based } \\
\text { on FSM (free school meals) } \\
\text { and size of school roll -mean } \\
\text { FSM - } 6.9 \% \text { and }<200\end{array}$ & $\begin{array}{l}9 \text { control classes } \\
\text { with normal lessons. } \\
9 \quad \text { intervention } \\
\text { classes received } \\
\text { CBT. } \\
4 \text { classes were taught } \\
\text { by teachers. } \\
5 \text { classes taught by } \\
\text { psychologists. }\end{array}$ & $\begin{array}{l}\text { Intervention group showed better } \\
\text { signs of using coping mechanisms to } \\
\text { manage anxiety. No differences } \\
\text { between teacher or psychologist led } \\
\text { intervention groups. } \\
\text { Promising that universal intervention } \\
\text { across schools worked well and } \\
\text { teachers could run the program. } \\
\text { Potential for all children to benefit, }\end{array}$ \\
\hline
\end{tabular}




\begin{tabular}{|c|c|c|c|c|}
\hline & & students. & & $\begin{array}{l}\text { easier and cost efficient to implement } \\
\text { in school. }\end{array}$ \\
\hline $\begin{array}{l}\text { Gillham, J. Reivich, K. } \\
\text { Jaycox, L. Seligman, } \\
\text { M. } \\
\text { Prevention of } \\
\text { depressive symptoms in } \\
\text { school children: two } \\
\text { year follow up. }\end{array}$ & $\begin{array}{l}\text { USA } \\
1995\end{array}$ & $\begin{array}{l}5 / 6^{\text {th }} \text { graders at time of } \\
\text { intervention (age 10-12). } \\
118 \text { children - } 69 \text { intervention, } \\
49 \text { children control. } \\
\text { Children who scored } 0.50 \text { or } \\
\text { higher on Childhood } \\
\text { Depression Inventory invited } \\
\text { to participate and tracked for } \\
\text { two years after intervention. }\end{array}$ & $\begin{array}{l}\text { Intervention group } \\
\text { taught cognitive and } \\
\text { problem solving } \\
\text { skills. } \\
\text { Control group, no } \\
\text { intervention. } \\
\text { Children were } \\
\text { matched for sex, } \\
\text { race and parental } \\
\text { marital status. }\end{array}$ & $\begin{array}{l}\text { Fewer depressive symptoms for the } \\
\text { intervention group. } \\
\text { Two years later: Depressive } \\
\text { symptoms continued to decrease in } \\
\text { the intervention group who displayed } \\
\text { improved explanatory style. } \\
\text { Depressive symptoms increased for } \\
\text { the control group. } \\
\text { Age 10/11 potentially a good time for } \\
\text { intervention. Important time to } \\
\text { change trajectories? }\end{array}$ \\
\hline $\begin{array}{l}\text { Lubans, } \\
\text { Plotnikoff, } \\
\text { Lubans, N. J. } \\
\text { A systematic review of } \\
\text { the impact of physical } \\
\text { activity programmes on } \\
\text { social and emotional } \\
\text { wellbeing in at risk } \\
\text { youth. }\end{array}$ & $\begin{array}{l}\text { Australia } \\
2012\end{array}$ & $\begin{array}{l}\text { Review of the literature. Looks } \\
\text { at activity programs including: } \\
\text { outdoor activities, sport and } \\
\text { skill based and physical fitness } \\
\text { based programmes. } \\
\text { Also conducted a bias } \\
\text { measurement based on factors } \\
\text { such as measurements, } \\
\text { whether the assessors were } \\
\text { blind, whether control factors } \\
\text { were present. } \\
\text { Looked at } 15 \text { separate } \\
\text { programs. }\end{array}$ & N/A & $\begin{array}{l}\text { Some good evidence that activity } \\
\text { groups do have positive effects and } \\
\text { outcomes for those who were at risk } \\
\text { who used the groups. Several found } \\
\text { significant results in terms of } \\
\text { resilience, self-concept, } \\
\text { self-perceptions, perceived physical } \\
\text { competence and mood regulation. } \\
\text { Outdoor activities seemed to have the } \\
\text { best outcomes. The activity has to be } \\
\text { engaging and provide young people } \\
\text { with meaningful experiences. } \\
\text { Recruitment and retention for at risk } \\
\text { young people is very difficult, makes } \\
\text { increasing the evidence base difficult. } \\
\text { Hard to know what is the real reason } \\
\text { for improvements, some suggestion } \\
\text { that a new environment is a big } \\
\text { factor? }\end{array}$ \\
\hline $\begin{array}{l}\text { Martin, K. Sharp, C. } \\
\text { Mehta, P. } \\
\text { The impact of the } \\
\text { summer schools } \\
\text { programme on pupil.s }\end{array}$ & $\begin{array}{l}\text { UK } \\
2013\end{array}$ & $\begin{array}{l}\begin{array}{l}\text { Survey of } 21,065 \text { year } 6 \\
\text { students from treatment } \\
\text { schools and comparison } \\
\text { schools. }\end{array} \\
877 \text { schools that participated in } \\
\text { summer schools. } \\
\text { Children were invited from a } \\
\text { disadvantaged background } \\
\text { following the pupil premium. } \\
\text { Children not from a }\end{array}$ & $\begin{array}{l}\text { Summer school was } \\
\text { run by the secondary } \\
\text { school that the } \\
\text { children were going } \\
\text { to enter in their next } \\
\text { term. } \\
\text { Phase 1: survey to } \\
\text { school, randomly } \\
\text { chosen across the } \\
\text { country who took } \\
\text { part in the summer } \\
\text { school project. }\end{array}$ & $\begin{array}{l}\text { Children and schools thought it was } \\
\text { very successful, would take part } \\
\text { again and recommend it to further } \\
\text { students. } \\
\text { Children said they were less anxious } \\
\text { about attending their new secondary } \\
\text { school. They were not sure it would } \\
\text { have any lasting impact on their } \\
\text { educational work. } \\
\text { Those who had free school meals or } \\
\text { were looked after children seemed to } \\
\text { get more out of the summer school }\end{array}$ \\
\hline
\end{tabular}




\begin{tabular}{|c|c|c|c|c|}
\hline & & $\begin{array}{l}\text { disadvantaged background did } \\
\text { take part in the summer } \\
\text { schools where 'first choice' } \\
\text { children refused invitations to } \\
\text { join }\end{array}$ & $\begin{array}{l}\text { Phase 2: case study } \\
\text { visits - chose due to } \\
\text { variations in } \\
\text { demographics. } \\
\text { Phase 3: a pupil } \\
\text { survey. }\end{array}$ & $\begin{array}{l}\text { than children who were not from a } \\
\text { disadvantaged background. } \\
\text { Children enjoyed the project and } \\
\text { recruitment and attrition rates are } \\
\text { good. } \\
\text { There is a concern that those who } \\
\text { would benefit the most declined to } \\
\text { take part. The report does not make } \\
\text { any suggestions about the need for } \\
\text { summer projects to engage with those } \\
\text { most at risk. }\end{array}$ \\
\hline $\begin{array}{l}\text { Roberts, C. Kane, R. } \\
\text { Thomson, H. Bishop, } \\
\text { B., Hart, B. } \\
\text { The prevention of } \\
\text { depressive symptoms in } \\
\text { rural school children, a } \\
\text { randomized controlled } \\
\text { trial. }\end{array}$ & $\begin{array}{l}\text { Australia } \\
2003\end{array}$ & $\begin{array}{l}7^{\text {th }} \text { graders (Age 11-12). } \\
189 \text { children - } 90 \text { intervention, } \\
99 \text { control group. } \\
\text { Child depression inventory } \\
\text { scale (CDI). } \\
\text { The } 13 \text { highest scores for } \\
\text { depressive symptoms in a class } \\
\text { asked to participate. } \\
\text { Randomly assigned to either } \\
\text { control or intervention group. }\end{array}$ & $\begin{array}{l}\text { Control group had } \\
\text { normal health } \\
\text { lessons. } \\
\text { Intervention group } \\
\text { were taught skills, } \\
\text { including coping and } \\
\text { being assertive. }\end{array}$ & $\begin{array}{l}\text { Very little difference between control } \\
\text { and intervention groups. } \\
\text { Intervention group showed some } \\
\text { improvement in signs of anxiety } \\
\text { which may have a positive effect on } \\
\text { depressive symptoms but that is not } \\
\text { evidenced in this project. } \\
\text { Little benefit sustained over } \\
\text { post-intervention follow ups. } \\
\text { Potentially targeted the children too } \\
\text { late-they were already in secondary } \\
\text { school. }\end{array}$ \\
\hline $\begin{array}{l}\text { Siddiqui, N. Gorard, S. } \\
\text { See, B. } \\
\text { Is a summer school } \\
\text { programme a promising } \\
\text { intervention for } \\
\text { transition from primary } \\
\text { to secondary school? }\end{array}$ & $\begin{array}{l}\text { UK } \\
2014\end{array}$ & $\begin{array}{l}\text { Year } 6 \text { (11 year olds). } \\
160 \text { children. } \\
\text { Children invited from schools } \\
\text { in North East London - it is } \\
\text { not explicit how children were } \\
\text { asked to attend. Some children } \\
\text { had FSM but not all were from } \\
\text { disadvantaged backgrounds. }\end{array}$ & $\begin{array}{l}4 \text { weeks of summer } \\
\text { school. } \\
\text { Children attended } \\
\text { school where they } \\
\text { had literacy and } \\
\text { numeracy classes in } \\
\text { the morning and } \\
\text { activities in the } \\
\text { afternoon. } \\
\text { Control group data } \\
\text { was collected from } \\
\text { children who did not } \\
\text { attend the summer } \\
\text { school. }\end{array}$ & $\begin{array}{l}\text { No clear results from the program } \\
\text { and no educational attainment } \\
\text { differences } \\
\text { Children generally enjoyed the } \\
\text { program but activities weren't always } \\
\text { as promised and the whole project } \\
\text { felt more like school than something } \\
\text { different and enjoyable. } \\
\text { The project presented the question of } \\
\text { whether a summer school could work } \\
\text { to aid the transition for children from } \\
\text { disadvantaged backgrounds } \\
\text { minimize 'summer loss.' The report } \\
\text { concludes the program was largely } \\
\text { enjoyed rather than stating any real } \\
\text { benefits to the children who attended. }\end{array}$ \\
\hline
\end{tabular}

\section{Copyrights}

Copyright for this article is retained by the author(s), with first publication rights granted to the journal.

This is an open-access article distributed under the terms and conditions of the Creative Commons Attribution license (http://creativecommons.org/licenses/by/4.0/). 